\title{
Isaiah Kenen, President Eisenhower, and Aid to Israel During the Suez Crisis
}

\author{
By: Kobby Barda
}

This paper looks at one important stage in Isaiah Kenen's establishment of the American Israel Public Affairs Committee, now one of the strongest and most influential American lobby groups, and the most important one in the realm of foreign affairs. Kenen used a management theory that allowed AIPAC to grew into the organization we see and know today, and he developed a method that allowed the organization to impact Israel's relationship with the US. But how did this "one-man show" recruit and mobilize thousands of people-as early as the eventful months surrounding Israel's Sinai War? This incident, concerned with what is known outside of Israel as the Suez Crisis, forms the stage I want to focus on.

The paper's analysis will therefore start from an overview of key points that Kenen outlined in a letter during this period (1956-57) attached directly to President Eisenhower's changing views on Israel and the Middle East. I will then highlight my research pertaining to Kenen's management of the organization that informed Eisenhower's policy, looking at how Kenen during the years around this time built the organization's power. I will emphasize that he used an inverted-pyramid management theory combined with what has become known as the Nordstrom model of management. ${ }^{1}$ In this way I wish, through Kenen's eyes, to examine the network he built as he laid the foundation for a volunteerbased structure-and a central headquarters capable of mobilizing it. I have chosen this

1. Robert Spector \& Patrick D McCarthy, The Nordstrom Way: The Inside Story of America's \#1 Customer Service Company. Wiley, 1995. 
point of view in order to better understand the symbiosis created between Kenen's supporters and American policy makers, as well as the strategic relationship between Israel and the US.

\section{American Jews in the International Arena}

It was in 1955 that the British government had begun to apply intense pressure on Israel. In response, the organization that was to become AIPAC rallied to pressure the British Embassy in Washington. Kenen sent a letter to 2,500 Zionist community leaders, asking them to make it clear to their representatives and local media why Israel needed to be backed at the time. According to Kenen, the Arab countries were applying pressure to paint Israel as a country opposing peace, in a move that brought them closer to the USSR and endangered the Israel-US alliance. In his letter, Kenen voiced his concern that Israel would be outmaneuvered and forced into a corner-in a way like Czechoslovakia during Prime Minister Chamberlain's time. Therefore, Kenen wrote, pressure must be applied to the British ambassador and other British representatives around the country, to make it clear that Israel must not be singled out or otherwise isolated.

As usual, Kenen included a practical toolkit for his messengers, giving them ideas and guidance as to how to get things done. In this letter he listed five talking points to be used in conversations or letters initiated by the Israel supporters.

(1) Arab countries have no territorial claims to the 1948 borders. $^{2}$ (Moreover, they rejected that compromise, and Israel readily accepted that rejection.)

(2) The British-American alliance is based on mutual interest. (Both countries want to maintain democracy and liberties, as does Israel.)

(3) Jewish trust in British policy has been affected by past events, including the 1938 Munich deal and White Books on migration to Palestine. (The UK would do well not to have another item on that list.)

2. This is written before the 1967 Six Day War and the territorial disputes we are used to discussing today. 
(4) Any attempt to maim or weaken Israel seems like a gift to the Arab states, and not one which will advance peace.

(5) The Second World War broke out following the Munich deal and unfounded promises of peace that were not fulfilled.

Throughout the letter, it is easy to see the simple but effective messages sent to 2,500 people. Kenen hoped they would pass them on, creating a flurry of public pressure against the British and in support of Israel.

So, what were the effects of Kenen's letter, and how was he able to realize those through the developing organization that would soon become known as AIPAC? I will now turn to a history of Kenen's involvement in Jewish affairs, as they led directly to his successful action and influence in this case. Again, it was a case of reaching President Eisenhower with a message that would change the president's views on policy for the Middle East.

\section{Background: The American Zionist Council}

The early days of Israel as modern nation-state were marked by the importance of exchanges among various organizations, exchanges which would lend to-or follow upon-David Ben-Gurion's declaration of May 14, 1948. As Ben-Gurion established the state of Israel, the importance of the moment was clear in relation to the devastating struggles of the Second World War, the end of the British Mandate on Palestine, and the United Nations' Partition Plan. While all of this is well known, the importance of support from within the United States is noteworthy because it belongs to the Zionist movement in that country, a popular movement that mobilized American organizations in support of Israel. These organizations would continue to deal on behalf of Israel, directly with Congress and especially with the Senate, as masses of people impacting their representatives at the state level, empowered by a newsletter that kept the issues clear over time. It remains clear today that this newsletter, as a central example of how the Zionist cause 
advanced within American politics at the time, was important not only for individuals but at another operative level: the wider community.

Reaching community members who could apply pressure on specific congressmen was of key importance to the emerging lobby known, in its first iteration, as the American Zionist Council. The AZC had been founded in 1949 to consolidate the Zionist cause following Israel's War of Independence, and by 1951 it had given rise to the more formal organization known as the American Zionist Committee for Public Affairs. In 1959, the AZCPA would become what we know today as AIPAC: the American Israel Public Affairs Council. So, while this paper is focused on the organization known today as AIPAC, I will examine how it was able to develop so quickly that it had a direct impact on the Sinai War of 1956. The Suez Crisis came during that phase of the organization's history where it was known as the AZCPA, and Kenen was arguably the single individual most responsible for the organization's remarkable consistency of vision throughout these early days.

\section{Founding The American Zionist Committee for Public Affairs}

Kenen, born in Canada, had established himself as a journalist and lawyer in Ohio and had gone on to act as secretary general of the American Jewish Conference from 1943 to 1947. His further efforts (with the Jewish Agency and, particularly, Israel's delegation to the UN during the latter's deliberations over its partition plan) prompted AZC leader Louis Lipsky to "borrow" him in order to establish the AZCPA. This borrowing meant Kenen would move from the New York offices of Israel's first ambassador to the US, Abba Eban, and into Washington. From here, notably by setting up the newsletter that would become so influential, Kenen personally oversaw the organized movement of American voters to address their congresspeople on behalf of the AZCPA. Kenen has been described as having "a list of hundreds of key players all over the US, local rabbis 
and community leaders, who could pick up the phone and call their representatives." ${ }^{3}$ And just how broadly scattered, how widely present, AIPAC's early formation was throughout the US can be seen from the partial list of local representation in a letter sent to its national committee members. The organization was physically present in dozens of cities and communities across the country. ${ }^{4}$

\section{Mobilizing in an Inverted-Pyramid Formation}

In a letter from 1957, Kenen described the incoming requests by various communities after he had sent telegrams about a crisis involving Gaza and Egypt's leader, Gamal Abdel Nasser. ${ }^{5}$ Four hundred and sixty-two telegrams were sent from the Christian community in Atlanta, about one thousand from Dayton, Ohio, and another 8,500 or so from Texas. Kenen writes how Senator Johnson's office was "flooded" with letters from across the country.

These numbers highlight both the method and the growing importance of maintaining ties with non-Jewish community leaders and influencers. Another fascinating example is the work done by a small Jewish community in Providence, Rhode Island, which proves the effectiveness of the inverted-pyramid management structure. The local community sent a letter to Kenen, describing their chain of command. It all started when Kenen wrote to Judge Frank Licht, one of the people on his list, asking him to help involve the community. Upon receiving the letter, Licht sent immediate telegrams to all the community's communication council, calling an emergency meeting for the following dayFebruary 24, 1957. Despite the short notice, seventy people showed up. They represent the next link in Kenen's chain. According to the testimonies, that same day saw 1,123

3. David H. Goldberg, Foreign Policy and Ethnic Interest Groups: American and Canadian Jews Lobby for Israel. Praeger,1990, p. 154.

4. Ibid. TENZER.

5. Ibid., Rochester, Box 3, Correspondence March-August 1957. 
telegrams sent from Providence to the president, to Secretary of State John Foster Dulles and to Rhode Island's senator, Theodore F. Green. Green also served, at that time, as chair of the Senate Foreign Relations Committee.

The testimony highlights the significant call to action, and how people went to the local branch of Western-Union, lining up to send their telegrams. At one point, it notes, the telegram employees simply could not handle the quantity; they requested that more people be sent to work. At the same time, the members of another Providence committee started writing letters to the editor, and op-eds, for local papers. This resulted in a lead item in the Providence Journal on Monday, the day after that emergency breakfast meeting.

In other words, a single telegram from Kenen (to Judge Licht) resulted in 1,123 telegrams to the decision makers, as well as headlines in local newspapers. This example from the small town of Providence illustrates the method perfectly. Once we understand it, it is easy to see just how wide Kenen's reach was when he sent not one telegram, but hundreds of them-including to communities much larger than the one in Rhode Island.

\section{Kenen Uses Pyramid to Fight Sanctions}

This paper's central example focuses on how Kenen mobilized the lobby's power during the early months of 1957 . His action came in answer to a White House threat: to sanction Israel in light of its military actions in the 1956 Sinai Campaign. France and Britain had also taken part in this invasion of Egypt, seeking to regain Western control of the Suez Canal-and, ultimately, to remove Gamal Abdel Nasser from the Egyptian presidency. In the events leading up to this crisis, Nasser had nationalized the canal. And the events of the crisis put considerable pressure on the question of Israel's legitimacy, notably in the eyes of President Eisenhower. 
In February 1957 this pressure reached its boiling point. On January 17, President Eisenhower had announced the US would not make any more concessions to Israel and, on February 2, there were two resolutions tabled at the United Nations. The first called for an immediate withdrawal of Israeli forces from the Sinai Peninsula, which it had captured from Egypt in aid of Britain and France during their fight for the Suez Canal. Seventy-one countries supported the resolution. Then, a resolution calling for peace efforts to follow the withdrawal was put to a vote. It was supported by fifty-six countries. Following the votes, UN Secretary General Hammarskjöld demanded Israel announce it had completed its military withdrawal from Sinai by midnight of February 7. Israel officially rejected the possibility, and the US administration started to look at the idea of placing sanctions on Israel.

To fully understand these events, one has to take a look at the political climate in which they unfolded. So, a slightly wider view of what was happening at the time will allow greater clarity in our focus on the Suez events.

On January 5, 1957, Eisenhower had ceremoniously unveiled his plan to stop communist influence in the Middle East. This was the doctrine he was advancing in his policy on the Middle East. At the same time, American pressure on Israel to pull out of Sinai increased. On January 6, US Ambassador Lawson met with Israeli Prime Minister David Ben-Gurion, handing him a personal letter from Secretary Dulles which demanded an immediate withdrawal from Sinai. ${ }^{6}$ The American pressure was important to the president, who completed the public presentation of his plan and hoped he could stop communism from entering that part of the world. According to Ben-Zvi, at its base the Eisenhower doctrine lay on what the president summarized as follows:

6. Lawson Demands Ben-Gurion Unconditional Withdrawal. Hatzofe, January 8, 1957. National Library Jewish Press Archive [accessed June 16, 2019]: http://www.jpress.nli.org.il/Olive/APA/NLI heb/SharedView.Article.aspx?href=HZH\%2F1957\%2F01\%2F08\&id=Ar00107\&sk=752CCC95 
the Administration's obligation to send military forces to guarantee the territorial and political independence of the countries asking the US for aid and protection against a threat based in the states gripped by international communism. The main goal of the doctrine was to deter Egypt from intervening - directly or indirectly -in countries like Jordan or Lebanon, while, at the same time, using economic and military aid to strengthen moderate regimes in the Middle East. $^{7}$

On January 15, 1957-six days before he was sworn into office for his second term-Secretary Dulles gave testimony to the Senate's Committee on Armed Services in which he announced that sanctions against Israel would continue. ${ }^{8}$ It was at this point that Kenen started working in high gear, as described in his correspondence with Philip Bernstein (who chaired the AZCPA and AIPAC during the period from 1954 to 1968). In what he called "wave after wave" of action, Kenen details the steps he took to mobilize everyone he could through the pyramid so they would apply pressure-starting with letters to Congress, so they could pressure the State Department. According to the note sent by Kenen, and backed by open sources from that period, a rather clear picture is painted regarding Kenen's method of mobilizing people to action. This method worked through organizations as well as individuals, with the goal of improving the situation for Israel, which was then under immense American pressure.

Over 3,500 Jewish leaders received requests to call their representatives in the House or in the Senate, or to flood the capital with telegrams detailing the "double moral standard" of the United Nations, which demanded Israel withdraw from the Sinai Peninsula without providing guarantees for free passage of ships in the Straits of Tiran. At the same time, Kenen started calling community leaders in New Orleans, New Jersey and Texas, asking them to work their congressional representatives. At one point, Kenen

7. (Hebrew Source) Avraham Ben-Zvi, The US in the International Arena Since 1954. Israel Open University, 2006, p. 95.

8 Dulles: Aid to Israel, Egypt and Jordan to Remain Frozen. Davar, January 16, 1957. National Library Jewish Press Archive [accessed June 16, 2019]: http://www.jpress.nli.org.il/OIive/APA/NLI heb/SharedView.Article.aspx?href=DAV\%2F1957\%2F01\%2F16\&id=Ar00108\&sk=8D451DC4< 
describes how Senator Margaret Smith's office told him they had received over five hundred telegrams from residents of Maine-in a single day. This intensive work on Kenen's part had results in the field.

As mentioned, on January 25, one paper reported seventy congressmen had called on Secretary Dulles to ease the pressure on Israel. The body of the article informed readers that "Democratic Congressmen had written to Secretary of State Dulles to express their concern regarding the pressure on Israel to withdraw before being given guarantees about freedom of movement in the Tiran Straits." The congressmen also wrote that they understood Israel had "no desire to annex this area or keep it," aiming instead to ensure it would not be attacked and that its trade would not be hurt. This was why, they concluded, "we can understand Israel's concerns."9

As this unfolded among members of Congress, another front on which Kenen's public leverage worked well was the Texan front. In a letter on which Kenen is carboncopied, Senator Lyndon Johnson (who at the time was the Senate Majority Leader and would later go on to become president) wrote to Secretary Dulles. Johnson told Dulles "how troubled I am by what I have read in the newspapers about sanctions on Israel," ending the letter by saying he hoped Dulles would "instruct the American mission to the UN to oppose measures against Israel, with all the good tools" at Dulles's disposal. ${ }^{10}$ This was published as an open letter, and it was described by various outlets as a threat to the Eisenhower administration's doctrine. One Hatzofe article in Hebrew noted that "the Majority Leader in the Senate, Lyndon Johnson of Texas, expressed his opinion that

9. Seventy Congressmen Demand Dulles Stop Pressuring Israel. Hatzofe, January 25, 1957. National Library Jewish Press Archive [accessed June 16, 2019]: http://www.jpress.nli.org.il/OIive/APA/NLI heb/Print.Article.aspx?mode=image\&href=HZH\%2F1957\%2F01\%2F25\&id=Ar00111\&rtl=true 10. Ibid., Rochester, Box 3, Correspondence, January-February \& March-August 1957. 
President Eisenhower should refrain from using forceful measures in the relationship between the U.S. and Israel."11

Jewish pressure on the administration was mounting at a moment where President Eisenhower had other plans for the region as part of his doctrine of increased American influence in the Middle East. For instance, on February 4, 1957, the president was quoted as being "worried by Israel's aspirations to expand," 12 according to a letter he had sent to King Saud of Saudi Arabia. Earlier, the king had told him he was tentatively accepting the American doctrine, which had been officially presented to him. In the king's letter, he explained it was conditioned on the US "showing a willingness to harness Israel, since Israel was a greater threat than the USSR." He also packaged this together with Saudi Arabia's willingness to extend leases for American air force bases in the kingdom, a strategic asset Washington would not easily let go of. According to the report in an Israeli newspaper, Eisenhower replied by expressing his "sincere worry" over "Israel's aspirations to expand its territory," to which he added a list of steps he had taken, and would take, in retaliation to the military campaign in the Sinai.

As this was happening, Kenen's work brought forth its important results. The most important, some might argue, was a clear bi-partisan opposition to the planned sanctions against Israel. On February 21, 1957, the heads of Congress arrived at the White House to discuss the issue. During the meeting they informed the president's team they would oppose sanctioning Israel. An Israeli newspaper reported that the meeting "between the

11. Heads of Congress Oppose Sanctions. Hatzofe, February 21, 1957. National Library's Jewish Press Archive [accessed June 16, 2019]:

<http://www.jpress.nli.org.il/Olive/APA/NLI heb/Print.Article.aspx?mode=image\&href=HZH\%2F1957\%2F02\%2F21\&i $\underline{d=A r 00100 \& r t l=t r u e ~}>$.

12. I Am Worried by Israeli Aspirations. Hatzofe, February 4, 1957. National Library's Jewish Press Archive [accessed June 16, 2019]:

shttp://www.jpress.nli.org.il/Olive/APA/NLI heb/Print.Article.aspx?mode=image\&href=HZH\%2F1957\%2F02\%2F04\&i $\underline{d=A r 00204 \& r t l=t r u e>}$ 
heads of Congress and President Eisenhower ended without results, after the leaders of both parties vocalized their objection to one-sided sanctions against Israel for its unwillingness to withdraw without guarantees."13

Special attention was placed on members of the House and Senate, who were marked by Kenen in a letter to Bernstein. Kenen was working to recruit support on both sides of the isle, and he targeted specific players he saw as crucial to this cause. Senator William Knowland (Rep., California), a friend of the president and Senate Minority Leader, was one such person. Another was the Senate Majority Leader, Johnson. In an article about their joint meeting with the president, both are quoted as opposing the sanctions, with Johnson adding he "had not heard a single thing" that would make him change his position on the issue.

On February 22, 1957, Israel's ambassador to the US and the United Nations, Abba Eban, flew to Israel for a special top-classified secret cabinet meeting on the American ultimatum. The ultimatum would have forced Israel to withdraw without any guarantees regarding freedom of shipping to Israel's port city of Eilat. In the then-classified protocol ${ }^{14}$ from the meeting, Kenen's continuous efforts, along with those of others in the Jewish community, were apparent. They were apparent not only in the specific context of the discussion, but also throughout the overall American political system, which had now seen a sitting president reelected for his second term in a one-sided victory.

13. Heads of Congress Oppose Sanctions. Hatzofe, February 21, 1957. Taken from the National Library's Jewish Press archive [June 16, 2019]:

<http://www.jpress.nli.org.il/Olive/APA/NLI heb/Print.Article.aspx?mode=image\&href=HZH\%2F1957\%2F02\%2F21\&i $\underline{d=A r 00100 \& r t \mid=t r u e>}$

14. Cabinet Session 42/1957. From the National Archive [accessed June 16, 2019]:

<http://www.archives.gov.il/archives/\#/Archive/0b0717068031be30/File/0b07170680348355//tem/09071706803484bf $\geq$ 
In the discussion, Eban said there had been "significant movement in the public opinion regarding making our stubborn case heard." He then described an additional factor in making this happen:

the full mobilization of the public opinion, which was almost unparalleled in recent year, sympathy with Israel which not only brought together the Jewish People and resurrected it, but also build significant diplomatic institutions. This is [seen] among people we knew supported us, as well as those who we were not aware of their support. There is no doubt this mobilization of the public surprised the US Administration, but one incident stood above the rest, in a surprising way: Senator Knowland's position. For two years I had spoken to him almost monthly. But he was cold, even apathetic, and showed no willingness to even side with the idea. However, suddenly, he showed a direct support with Israel's issues, the double-standard at the UN when dealing with the Middle East compared to Russia and Hungary. Some say you can't tell what his endgame is, others view this as the start of his 1960 Presidential campaign.${ }^{15}$ Either way this appearance of his highlighted the place the American public stands regarding our demands for minimal guarantees of safety and security, at sea and on land, before anything. ${ }^{16}$

In light of this, Eban continued to explain why this position helped Israel in its bargaining with the American president, noting the countries would be entering "the last battle of negotiations" between the two sides.

It is almost certain, that the American President sees himself bound to his word to evacuate [Sinai]. Not only because of his pledge to the UN, but also to the American People. There is testimony he has promised our withdrawal to Arab rulers. True, he did not promise how he could achieve this—by force, influence or agreement, but he sees himself bound to his world: to ensure we evacuate the territories we conquered. ${ }^{17}$

This demonstrates how Kenen's work gave Israel the breathing room it needed to stand its ground, demanding American guarantees before leaving the Sinai Peninsula.

15 Knowland ended up running for, and losing, the governorship of California. 16 lbid., Cabinet.

17 lbid. 
Right after the cabinet meeting, Ben-Gurion traveled to the Knesset, Israel's Parliament, where he let members of the Foreign Affairs Committee know that he would oppose Eisenhower's demand for an unconditional withdrawal. ${ }^{18}$

Almost at the same time, Senator Knowland introduced the "Knowland Plan," in which he demanded sanctions be imposed against all countries who disobey the UNand not only Israel. ${ }^{19}$ The proposal was made to Eisenhower in the presence of twentyeight other legislators. Article three of the paper suggested the UN could take over land handed back by Israel, creating a buffer zone between it and Egypt with international presence and supervision-a position very close to that of the Israeli government. As Eban had testified to the cabinet, this was an extremely surprising move. Knowland was one of the most important leaders in the president's own party. His alternative plan provided a crucial counterweight to Eisenhower's own, as it broke party lines and opened alternative options. On the morning of February 25, the Senate leadership once again met-this time with Secretary Dulles—to discuss the Middle East. Majority Leader Johnson made it clear sanctions would not be awarded without a fight in Congress.

During all this time, Kenen had been busy in the background, doing everything possible to pressure senators so they, in turn, would apply pressure to the White House. ${ }^{20}$ In a letter from March 1, 1957, Kenen described to Bernstein the answers he received

18 (Hebrew Source) Prime Minister Speaks to Foreign Affairs Committee. Hatzofe, February 25, 1957. National Library's Jewish Press Archive [accessed June 16, 2019]:

<http://www.jpress.nli.org.il/Olive/APA/NLI heb/SharedView.Article.aspx?href=HZH\%2F1957\%2F02\%2F25\&id=Ar00 103\&sk $=22 E 80247$

19. (Hebrew Source) The Knowland Plan. Hatzofe, February 21, 1957. National Library's Jewish Press Archive [accessed June 16, 2019]: http://www.jpress.nli.org.il/Olive/APA/NLI heb/Print.Article.aspx?mode=image\&href=HZH\%2F1957\%2F02\%2F21\&id=Ar00102\&rtl=true 20. Dulles Discusses Sanctions, Eisenhower Plan with Senate Leadership. Hatzofe, February 25, 1957. National Library Jewish Press Archive [Accessed June 16, 2019]: 
from communities after mobilizing them via his organizational pyramid—using telegrams to reach them, and having them use telegrams to reach their representatives in Washington. ${ }^{21}$

Finally, in the early days of March, Israel decided to fully pull out of Gaza and the Sinai, in part because the US had made public assurances it would allow free passage of ships in the Suez Canal. This proclamation, as stated by Secretary Dulles at a press conference, ${ }^{22}$ provided the grace needed for Ben-Gurion to backtrack from his game of hardball while still claiming victory for Israel.

\section{Conclusion}

Another way of understanding Kenen's machine is by looking at the reactions various American politicians made to the pressure applied on them by Kenen's messengers from among their constituents. One such example, from the year before the Suez Crisis, was Congressman Samuel Friedel (Dem., Maine). In a letter from October 1955, Kenen's trustworthy assistant Rita Grossman described to Bernstein the pressure being put on Friedel. ${ }^{23}$ In her letter, she detailed how the congressman received letters from his constituents objecting to the State Department's approach in arming the Egyptian army. His office, in turn, requested that AZCPA draft him a letter which he could send in his name to state the issue. Grossman mentioned that the letter had already been drafted, and then asked Bernstein if it should still be passed on-because circumstances had changed since their last conversation.

21 Ibid., Rochester, Box 3, Correspondence, January-February \& March-August 1957.

22. (Hebrew Source) Dulles: All Ships Deserve Free Passage to Eilat. Davar, March 6, 1957. National Library's Jewish Press Archvie [accessed June 16, 2019]:

<http://www.jpress.nli.org.il/Olive/APA/NLI heb/SharedView.Article.aspx?href=DAV\%2F1957\%2F03\%2F06\&id=Ar00 $110 \&$ sk $=03468281>$

23 Ibid., Rochester (Correspondence box 3 1955) \Bernstein Papers Correspondence Oct-1955. 
This is a special insight on Kenen's work. It shows not only his ability to mobilize, and not only how that mobilization pressures a congressman-but also how that congressman then turns back to Kenen as the person who can help him. Remember, this is 1955, after only one year during which the AZCPA has been chartered as an independent body -and less than five years since it started to work on the Hill. The organization is quickly developing toward its status as AIPAC.

One step Kenen took toward mobilizing the community was to introduce pre-Easter holiday briefings. Ahead of the Congressional Easter recess, Kenen would send a generic letter with key points on Israel-US relations relevant to the period in which the congresspeople would return to their home states. The idea was simple: community leaders would pass the letter down the chain, so that as many constituents as possible would express their concern over those topics to their representatives, be it by phone, by letter, or in personal meetings. This method, of preparing talking points for the voter at one end of Kenen's relay, is still in use today. Email and other digital communications have replaced older forms of communication, but the idea remains: all readers know what the important topics are, and they can raise them with their representatives in any way they see fit.

In one letter for example, Kenen turns to the community as follows:

the House will be on Easter recess from April 1-13. This creates a window of opportunity to set up a meeting with the Congressman representing you while he is home. In the next few days, please take operative steps to call your congressman and talk to him about developments in the Middle East. ${ }^{24}$

Kenen's organization and its operations had gone a long way in securing President Truman's recognition of the new state of Israel, leading to the 1951 bill that allotted American financial aid to Israel for resettling refugees. As this paper has shown, Kenen put a great deal of emphasis on the management structure he had built, and the place the

24. Ibid., Rochester, box 5, executive committeelFolder 3. 
Kenen, Eisenhower, and the Suez Crisis

individual voter had. This emphasis both affected change and also let the Washington headquarters know what was being done on the ground. 